\title{
Surface roughness of edge glued panels (EGP) of amazon maneged species
}

\author{
Rugosidade superficial de painéis (colados lateralmente EGP) de \\ espécies manejadas da amazônia
}

\author{
Roberto Daniel de Araujo ${ }^{1 *}(\mathbb{D})$, Joaquim dos $\operatorname{Santos}^{2}(\mathbb{D})$, Claudete Catanhede do Nascimento ${ }^{2}(\mathbb{D}$, \\ Cristiano Souza do Nascimento' (iD), Sâmia Valeria dos Santos Barros³ (iD), Maria da Paz Lima²
}

\author{
${ }^{1}$ Instituto Nacional de Pesquisas da Amazônia/INPA/PPGCFT, Manaus, AM, Brasil \\ IInstituto Nacional de Pesquisa da Amazônia/INPA, Manaus, AM, Brasil \\ 3Instituto Brasileiro do Meio Ambiente e dos Recursos Naturais Renováveis/IBAMA, Manaus, AM, Brasil \\ *Corresponding author: rdaniel@inpa.gov.br \\ Received in August 13, 2019 and approved in December 13, 2019
}

\begin{abstract}
In the Amazon, the sustainable use of wood is associated with technological research that indicates industrial use. Surface roughness of wood is an important criterion for assessing tool condition, machining performance and product quality. The objective of this study was to evaluate the surface roughness of five Amazonian woods used in the manufacture of EGP (Edge Glued Panels).The woods Angelim pedra, Angelim vermelho, Breu vermelho, Murici and Piãozinho, obtained from managed areas of the Amazon, were used in the manufacture of EGP panels. Surface treatments were performed with 120 and 180 grit sandpaper. Surface ripples (roughness) were measured using a digital roughness meter with needle ( $n=180$ readings). Physical and mechanical tests were performed on both wood and EGP samples, to verify the possible relationship between these properties and roughness. EGP Piãozinho presented better surface quality, which consists of lower roughness (lower surface wave height), while EGP Angelim pedra presented uneven surfaces. Surface quality was satisfactory when 120 grain sandpaper was applied to most products. The results showed a highly significant effect of roughness such as the physical-mechanical properties. The highlight of the study is the wood and EGP Piãozinho, because in all the tests, it always presented the best performances.
\end{abstract}

Index terms: Amazonian Wood; physico-mechanical propecties; MOR and MOEd.

\begin{abstract}
RESUMO
Na Amazônia o uso sustentável da madeira esta associado às pesquisas tecnológicas que indicam o uso industrial. A rugosidade superficial da madeira é um critério importante para avaliar as condições das ferramentas, o desempenho da usinagem e a qualidade do produto. O objetivo do estudo foi avaliar a rugosidade superficial de cinco madeiras amazônicas utilizadas na manufatura de painéis EGP (Edge Glued Panels). As madeiras Angelim pedra, Angelim vermelho, Breu vermelho, Murici e Piãozinho, obtidas de área manejadas da Amazônia, foram utilizadas na confecção de painéis EGPs. Tratamentos das superfícies foram realizados com lixas de granulometria 120 e 180 . As ondulações de superfície (rugosidade) foram medidas em rugosímetro digital com agulha ( $n=180$ leituras). Ensaios físicos e mecânicos foram realizados tanto nas madeiras quanto nas amostras de EGP, para verificação de possível relação entre essas propriedades e a rugosidade. EGP Piãozinho apresentou melhor acabamento superficial, que consiste na menor rugosidade (menor altura das ondulações superficiais), enquanto o EGP Angelim pedra apresentou superfícies irregulares. O acabamento superficial foi satisfatório quando aplicouse o tratamento com a lixa 120 para a maioria dos produtos. Os resultados evidenciaram efeito altamente significativo da rugosidade como as propriedades físico-mecãnicas. O destaque do estudo é a madeira e EGP Piãozinho, pois em todos os ensaios, apresentou sempre os melhores desempenhos.
\end{abstract}

Termos para indexação: Madeiras da Amazônia; Propriedades Físico-mecânicas; MOR e MOEd.

\section{INTRODUCTION}

The Brazilian Amazon has a great diversity of forest species with timber potential, however, few species are used commercially, leading to a very selective exploitation of the forest with negative impacts on the forest ecosystem. Knowledge about the timber industry and its relationships with the forest base is important to discipline the use of stockpiled resources under the new sector paradigm, which is sustainable development. Technological knowledge about wood properties is fundamental for increasing $\log$ yield, as well as the generation of standardized and ecoefficient products (Iwakiri et al., 2015; Nascimento et al., 2018). 
Research aimed at increasing the use of species for industrial use becomes a priority for regional development in the Amazon, in order to optimize forest exploitation under sustainable management. Another important factor for the sustainable use of wood is its application in the manufacture of reconstituted products such as chipboard, MDF and newly side glued wood panels (EGP). These products can be manufactured in larger dimensions, presenting greater dimensional stability and better distribution of mechanical strength, with quality gains and better cost-benefit ratio (Almeida et al., 2017; Costa Tienne et al., 2011).

Some visual characteristics of wood such as color, pattern and texture determine the quality of manufactured products. Surface properties of wood material are important in both production and post-production marketing. The roughness characterizes the irregularities of the wood surface and directly affects the glued products, as well as in the finishing step (coating). These irregularities can be determined by measuring the height, width and shape of the peaks and valleys caused during the machining process or by the anatomical structure of the wood itself (Aydin; Çolakoğlu, 2003; Kilic; Pürlusoy; Kurnali, 2018; Magoos, 2008; Pereira; Garcia; Nascimento, 2018).

The study of roughness is an important criterion for assessing tool condition, machining performance and product quality. Several studies have sought to evaluate the effect of machining on surface roughness. Kilic, Hiziroglu and Burdurlu (2006), studying the effect of Fagus orientalis and Populus tremulawoods machining, observed a decrease in roughness with the use of sandpaper with $>80$ grit size. Martins et al. (2011), evaluating the wood surface of Eucalyptus benthamii observed that the machining operations (planing x sanding) did not significantly affect the roughness of this wood. These different results can be explained by the particular cellular structure of each wood species, demonstrating the importance of studying the machining effect associated with the anatomical structure.

The efficiency of surface quality (painting, varnishing, etc.) applied for protecting, improving and increasing the economic value of the end product is closely linked to the wood surface smoothness. Lower surface roughness values mean fewer imperfections, making it easier to accept waterproofing products such as paints, glues, and varnishes (Dias Junior et al., 2015; Aslan; CosKun; Kilic, 2008). Roabe, Menezzi and Gonçalez (2017) evaluating the effect of surface quality of Micropholis venulosa wood with sanding and sealer application, observed a reduction in roughness that considerably improved surface quality.
There are few studies on roughness of Amazonian woods. Amorim et al. (2013) evaluated the roughness of wood from the Arapiuns - Tapajós (Pará, Brazil) extractive reserve, and observed that the species Virola michelii (Myristicaceae) and Trattinnickia burserifolia (Burseraceae) presented different roughness between the radial and tangential faces, concluding that there was influence of roughness with wood density. Pereira, Garcia and Nascimento (2018), studying woods from a managed native forest (Acre, Brazil), found that the texture of the wood significantly affected surface roughness, and sanding caused a reduction in ripples by $53 \%$, where the minimum was $21 \%$ for wood from Cariniana sp. (Lecythidaceae), and $\sim 70 \%$ for Pouteria guianensis (Sapotaceae).

In this context, the objective of this study was to evaluate the surface roughness of five Amazonian forest species used in the manufacture of EGP panels.

\section{MATERIAL AND METHODS}

The species used in this study have a high occurrence in the managed area of the Tropical Forestry Experimental Station of the National Institute of Amazonian Research - INPA, nucleus ZF-2, Km 23 in BR-174 $\left(02^{\circ} 37^{\prime}\right.$ to $02^{\circ} 38^{\prime}$ latitude $60^{\circ} 09^{\prime}$ to $60^{\circ} 11^{\prime}$ 'west longitude), Manaus - Boa Vista (Brazil).

Luizão and Vasconcelos (1993) defined the region's climate as Afi of Köppen, with an average temperature of $26^{\circ} \mathrm{C}$ (minimum $19^{\circ} \mathrm{C}$ and maximum $39^{\circ} \mathrm{C}$ ). Annual rainfall ranges from 1,800 to $2,800 \mathrm{~mm}$, with a rainy season from December to May and a dry season from June to November; The wettest months are March and April ( $>300 \mathrm{~mm}$ of rainfall) and the driest months are July, August and September ( $<100 \mathrm{~mm})$.

In this area, inventoried plots were explored within the activities of the project MCTI/CNPq INCT "Madeiras da Amazônia" whose mission is to promote high impact research in order to indicate the best use of species from the Amazon, as well as the indication of new species for the timber market.

Three individuals of each species were selected and processed in boards and planks and stored in a warehouse belonging to Portela Woods Ltda. (Manaus-Brazil) for a period of approximately three weeks $\left(\mathrm{T}=20 \pm 2{ }^{\circ} \mathrm{C}\right.$, $\mathrm{RH}=65 \pm 5 \%$ ). Thus, the woods were transported to the Wood Artifacts and Engineering Laboratory (LEAM/ INPA) where they were dried by the semi industrial microwave system (Easydry - Wu. M Gobler) until it reaches a humidity of approximately $12 \%$. Samples were taken from this material for registration and deposit in the 
Botanical Collection - Xylotheque/PCAC/INPA, as well as confirmation of field identification (Table 1).

The mechanical process of the samples was performed with a fixed circular saw, calibration planer and the planer, with analysis of speeds and thickness of the cut. Parts measuring $2.5 \times 5 \times 24 \mathrm{~cm}$ were made, and then finger joined $\left(10 \times 6 \times 1 \mathrm{~mm} / \alpha=30^{\circ}\right)$ in a the tupia sector (Portela Woods - Manaus / Brazil), and finally glued with EPI $\left(150 \mathrm{~g} / \mathrm{cm}^{2}\right)$ on a pneumatic press (MAQUIMÓVEL, Model PPQ 1200, $11.22 \mathrm{Kgf} / \mathrm{cm}^{2}$ ).

Determination of roughness: From the EGP panels specimens were taken in the dimensions of 14 x $10 \times 2.5 \mathrm{~cm}$, obtaining for nine samples $\mathrm{n}=45 \mathrm{each}$ species ( 5 species $\times 9$ repetitions). Initially they were climatized to $12 \%$ humidity and manual sanding, in the direction of the fibers. The sandpaper used was of 120 and 180 grit. Surface roughness was measured using a digital needle roughness meter (MITUTOYO RD001), following NBR 4287 (2002) where each sample was measured four times, being two measurements in the radial longitudinal section and two in the tangential longitudinal section, totaling 180 readings. ( 5 species $\mathrm{x} 9$ repetitions $\mathrm{x} 4$ readings).

Other physical and mechanical tests were performed on both wood and EGP samples to verify the possible relationship between these properties and roughness.

Apparent density: Density was determined according to NBR 7190 (1997), specimens were sized at
$2.5 \times 5 \times 50 \mathrm{~cm}$, with $12 \%$ fixed wood moisture, using the formula $\rho=\mathrm{m} / \mathrm{V}\left(\mathrm{Kg} / \mathrm{m}^{3}\right)$ and $\mathrm{n}=250(5$ species $\mathrm{x}$ 50 repetitions).

Dynamic elastic modulus - MOEd: In this methodology the variables, voltage wave, are obtained in Stress Wave Timer 239A equipment (Metriguard) and calculated by the formula Esw $=(\mathrm{L} / \mathrm{t})^{2} \times \mathrm{D} / \mathrm{g} \times 10^{-5}$, the samples here tested are the same as those used in the previous determination.

Mechanical tests (MOR and Tensile): Specimens were made to determine the tensile and flexion rupture modulus (MOR) (ASTM, 2005) using a universal machine - EMIC model DL-300kN with speed $12.7 \mathrm{~mm} /$ minute, where five types of EGPs (species) manufactured with EPI were evaluated, $\mathrm{n}=100$ ( 5 species $\times 2$ tensile / flexion tests $\mathrm{x} 10$ repetitions). The test specimens were sized at 35.72 $\mathrm{x} 1.92 \times 1.28 \mathrm{~cm}$.

The values of the results obtained in the physicalmechanical and chemical tests of the wood, as well as in the mechanical tests of the EGP's panels were submitted to the analysis of variance (ANOVA) with the assistance of the programs ASSISTAT 7.6 and STAT GRAPHIC CENTURION (Demo version), in order to verify if there was a statistical difference between the treatments. For data that differed statistically, that is, when the $\mathrm{F}$ value was significant $(\alpha=0.05)$, the Tukey mean test at $5 \%$ significance level was applied.

Table 1: Species used in the study and registered at INPA's Xylotheque (Brazil).

\begin{tabular}{|c|c|c|c|c|}
\hline $\begin{array}{l}\text { Common } \\
\text { name }\end{array}$ & Scientific name & Botanical family & $\begin{array}{l}\text { Xylotheque } \\
\text { record }\end{array}$ & General Characteristics* \\
\hline $\begin{array}{l}\text { Angelim } \\
\text { pedra }\end{array}$ & $\begin{array}{l}\text { Himenolobium } \\
\text { pulcherrimum } \\
\text { Ducke }\end{array}$ & Fabaceae & $X-8894$ & $\begin{array}{c}\text { Medium to high density wood, with } 13.13 \% \\
\text { moisture, yellowish brown heartwood with dark } \\
\text { brown spots, cream sapwood, coarse grain and } \\
\text { coarse texture. }\end{array}$ \\
\hline $\begin{array}{l}\text { Angelim } \\
\text { vermelho }\end{array}$ & $\begin{array}{c}\text { Dinizia excelsa } \\
\text { Ducke }\end{array}$ & Fabaceae & $X-7978$ & $\begin{array}{c}\text { High density wood, with a } 14.10 \% \text { humidity, light } \\
\text { reddish-brown heartwood, slightly different } \\
\text { from reddish-gray sapwood, large grain, medium } \\
\text { texture and gloss }\end{array}$ \\
\hline $\begin{array}{c}\text { Breu } \\
\text { vermelho }\end{array}$ & $\begin{array}{l}\text { Protium } \\
\text { puncticulaton } \\
\text { J. F. Macbr }\end{array}$ & Burseraceae & $X-1247$ & $\begin{array}{l}\text { Medium density wood, with a humidity of } 12.87 \% \text {, } \\
\text { generally exude resin, slightly distinct heartwood/ } \\
\text { sapwood, grayish brown to light reddish brown, } \\
\text { right grain, medium to fine texture. }\end{array}$ \\
\hline Murici & $\begin{array}{c}\text { Byrsonima crispa } \\
\text { Juss }\end{array}$ & Malphigiaceae & $X-8466$ & $\begin{array}{l}\text { Medium density wood, with } 12.70 \% \text { humidity, } \\
\text { dark brown color, indistinct heartwood, medium } \\
\text { texture and diffuse porosity. }\end{array}$ \\
\hline Piãozinho & $\begin{array}{c}\text { Micrandropsis } \\
\text { sclerorylon W. Rod. }\end{array}$ & Euphorbiaceae & $X-6145$ & $\begin{array}{c}\text { High density wood with } 14.03 \% \text { moisture, } \\
\text { heartwood and distinct sapwood, darkened } \\
\text { heartwood and yellowish sapwood, right grain; } \\
\text { and coarse texture }\end{array}$ \\
\hline
\end{tabular}

«INPA/CPPF (1991). 


\section{RESULTS AND DISCUSSION}

The roughness characterizes the irregularities of the wood surface, which are associated with the formation of the xylem tissue as well as the machining process. The results of the machinery calibration are presented in Table 2. The parameters regarding rotational speed, cutting and cutting thickness were essential for the surface quality of the processed parts. In the circular saw $\left(\mathrm{M}_{1}\right)$ the cutting speed is directly influenced by the rotational movement, generating greater cutting thickness when compared to the effects produced on the calibrator $\left(\mathrm{M}_{2}\right)$ and planer $\left(\mathrm{M}_{3}\right)$ machines.

Table 2: Machining used in the woods studied.

\begin{tabular}{cccc}
\hline \multirow{2}{*}{ Processing factors } & \multicolumn{3}{c}{ Mechanical process } \\
\cline { 2 - 4 } & $\mathrm{M}_{1}$ & $\mathrm{M}_{2}$ & $\mathrm{M}_{3}$ \\
\hline Spinning speed $-\mathrm{Vf}(\mathrm{rpm})$ & 5.74 & 3.50 & 3.45 \\
Cutting speed - Va $(\mathrm{m} / \mathrm{min})$ & 6.22 & 3.79 & 3.73 \\
Cutting thickness - H $(\mathrm{mm})$ & 3.00 & 0.50 & 0.50 \\
\hline
\end{tabular}

$\mathrm{M}_{1}$ : stand saw; $\mathrm{M}_{2}$ : joint calibrator; $\mathrm{M}_{3}$ : wood planer.
Cutting conditions are directly affected by rotational speed as well as cutting thickness, resulting in better wood surface quality, i.e. surface roughness increases with increasing feed rate (Li et al., 2017; Thoma; Peri; Lato, 2015). Magoos (2015) states that the most important operating parameters for obtaining a surface with low roughness would be the feed speed and the cutting speed.

According to Amorim et al. (2013) the wood surface can be evaluated by objective parameters such as roughness before and after the finishing process. The surface roughness results of the wood used in the manufacture of EGP are shown in Figure 1. The effectiveness of the reduction of sandpaper-treated undulations occurred in a decreasing way for all panels. It is noteworthy that both the sanding surfaces and those of sandpaper 120 and 180 presented ideal requirements for the manufacture of panels. The EGP Angelim pedra presented significant difference in the height of the undulations in relation to the surface roughness without sanding and in the other granulometries (120 and 180). With the exception of the Breu vermelho panel, the others presented similar behavior regarding the reduction of the surface undulation height, where the lowest roughness (120 grit) was used for the products based on the woods of Murici, Angelim vermelho and Piãozinho.

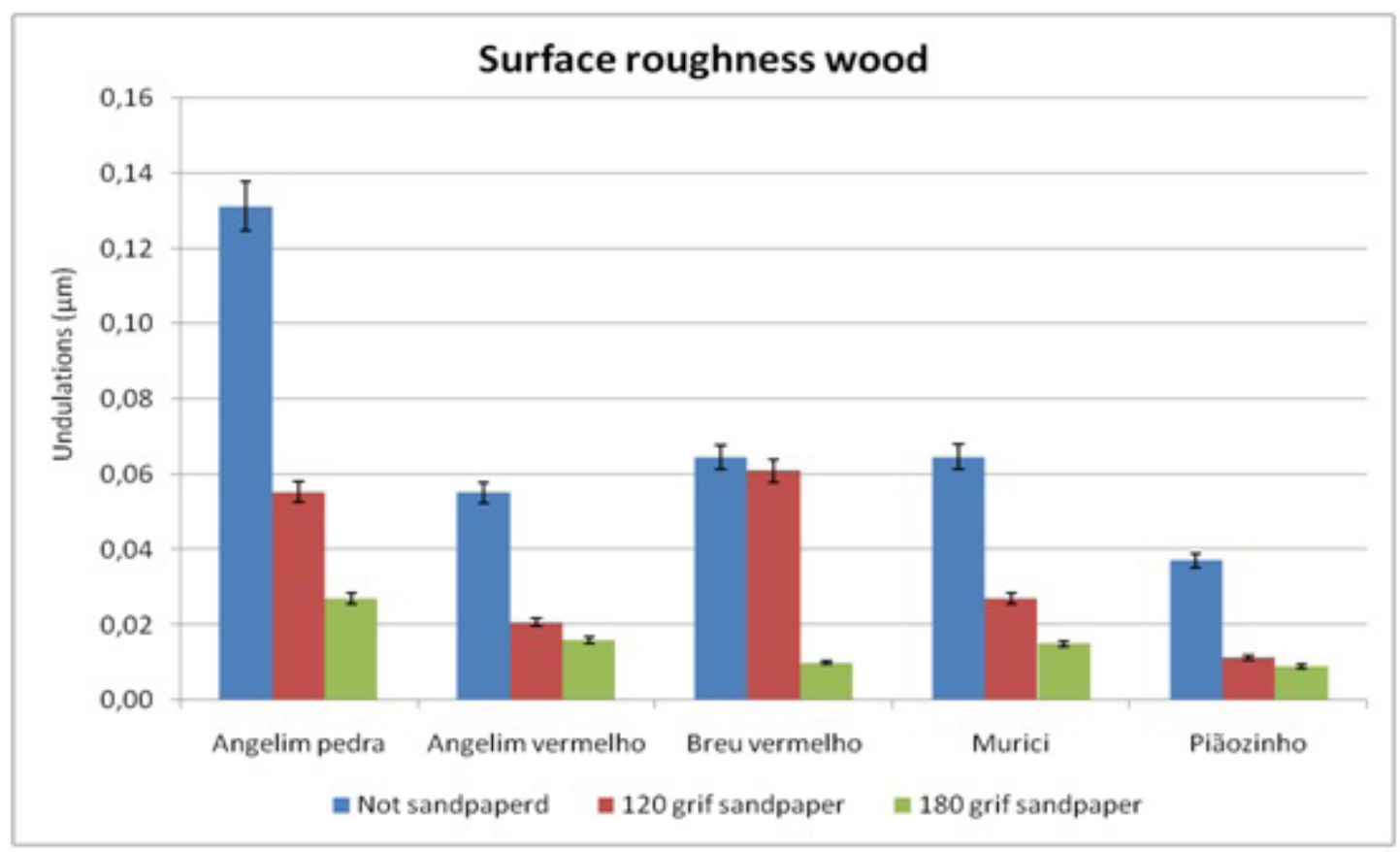

Figure 1: Surface roughness of Amazonian wood with and without sanding. 
The surface quality was satisfactory when the sandpaper $120(\mathrm{SL} / \mathrm{L} 120)$ treatment was applied to most products (50.73\%), except for EGP Breu vermelho which presented a low percentage difference of the undulations $5.60 \%$ (Table 3). However, when sandpaper 180 (L120/L180) was used, curl reduction was more effective at $82.54 \%$.

Table 3: Percentage difference of different finishes.

\begin{tabular}{ccc}
\hline \multirow{2}{*}{ Woods } & \multicolumn{2}{c}{ Percentage difference (\%)* } \\
\cline { 2 - 3 } & SL/L120 & L120/L180 \\
\hline Angelim pedra & $57.84 \mathrm{~b}$ & $50.80 \mathrm{~b}$ \\
Angelim vermelho & $62.38 \mathrm{a}$ & $19.63 \mathrm{~d}$ \\
Breu vermelho & $5.60 \mathrm{c}$ & $82.54 \mathrm{a}$ \\
Murici & $58.21 \mathrm{~b}$ & $41.92 \mathrm{c}$ \\
Piãozinho & $69.64 \mathrm{a}$ & $16.67 \mathrm{~d}$ \\
Average & 50.73 & 42.31 \\
\hline
\end{tabular}

$\mathrm{SL}=$ Not sandpapered; $\mathrm{L} 120$ = Sandpaper 120; $\mathrm{L} 180=$ Sandpaper 180; Means followed by the same letter do not differ statistically by the Tukey test at a probability level of $5 \%$.

The surface in natura of EGP Angelim pedra that presented greater roughness can be explained by its anatomy. According to Ferreira, Gomes and Hopkins (2004) and INPA/CPPF (1991) species of the genus Hymenolobium tend to present coarse texture and reverse grain. This behavior was observed by Thoma, Peri and Lato (2015) when assessing the surface roughness of the woods of the Albanian region (Abies alba, Pinus halepensis, Fagus sylvatica, Juglans regia and Quercus petraea).

According to Csanády, Magoss and Tolvaj (2015) and Thoma, Peri and Lato (2015) the high values of wood surface roughness are related to the anatomical structure, such as pore size and distribution, fiber size, texture, irregular grain, reverse or cross-linked, and cells filled with silica. Li et al. (2017) go further and add physical and mechanical properties as factors that influence surface roughness.

Kilic, Hiziroglu and Burdurlu (2006) while studying the effect of machining on the surface roughness of Fagus orientalis and Populus tremula woods found a decrease in roughness with the numerical increase of sandpaper grit. Pereira, Garcia and Nascimento (2018) while studying the roughness of Amazonian wood noted the reduction of roughness in the sandpaper-treated surface, having a percentage difference in roughness that ranged from 21.21 to $69.90 \%$ (flattened surface - sanded surface). For the EGPs studied, the use of 120 grit sandpaper presented a percentage difference of $50.73 \%$. These reductions are explained by Moura and Hernandez (2005) and also by Zhong, Ng and Hiziroglu (2018) who state that the sandpaper finishing process provides surface uniformity and minimizes anatomical influences.

Several studies associate roughness as a quality factor for timber products (Amorim et al., 2013; Li et al., 2017; Magoos, 2015), where this aspect is directly associated with the physical properties of wood, such as density, humidity and the strength of the panel when obtained in the bonding process, which is influenced by roughness. Table 4 presents the results of the physical and mechanical characterization of the EGPs manufactured with Amazonian managed woods.

Apparent density is calculated based on mass and bulk volume, with wood moisture fixed at $12 \%$. The results for the woods are presented in Table 4, which ranged from 760 to $1,180 \mathrm{Kg} / \mathrm{m}^{3}$, and these data are classified in high density woods. The Tukey test revealed that there were no differences between the values of the Angelim pedra, Angelim vermelho and Breu vermelho woods. It is also observed that Piãozinho wood obtained the highest value of this determination. For the Dynamic Elasticity Module (MOEd), which were obtained by the non-destructive technique Stress Wave Timer, the average result was $12,528 \mathrm{MPa}$, with Piãozinho wood presenting the highest resistance $(14,212 \mathrm{MPa})$, and the small Breu vermelho wood $(11,049 \mathrm{MPa})$. Statistical analysis of the data (Tukey test) defined two sets of groups $(a=14,053-14,212 ; b=$ 11,049 - 11,792).

The results for the rupture modulus (Tensile and Flexion) tests of the panels revealed that EGP Piãozinho showed high strength in the tests, while EGP Angelim pedra had the lowest values for tensile (11.06 MPa) and Flexion (29.21 MPa). For the Tensile/MOR, the Tukey test showed that there were no differences between the values of the Angelim vermelho, Breu vermelho and Murici EGPs. While for Flexion/MOR, statistical analysis showed differences only for EGP Piãozinho.

The evaluation of surface roughness is one of the important factors in production processes related to the adhesion of wood elements and final processing of finished products. Presenting a direct relationship with product quality associated with wood moisture, density and mechanical properties (Magoos, 2008; Thoma; Peri; Lato, 2015; Zhong; Ng; Hiziroglu, 2018). 
Table 4: Physical and mechanical properties of EGP panels and woods*.

\begin{tabular}{cccccc}
\hline Wood & $\begin{array}{c}\text { Apparent density } \\
\left(\mathrm{Kg} / \mathrm{m}^{3}\right)\end{array}$ & MOEd (MPa) & $\begin{array}{c}\text { Tensile MOR } \\
(\mathrm{MPa})\end{array}$ & $\begin{array}{c}\text { Flexion MOR } \\
(\mathrm{MPa})\end{array}$ & $\begin{array}{c}\text { Roughness } \\
(\mu \mathrm{m})^{\star *}\end{array}$ \\
\hline Angelim pedra & $890 \mathrm{ab}$ & $11,792 \mathrm{~b}$ & $11.06 \mathrm{c}$ & $29.21 \mathrm{~b}$ & $0.13130 \mathrm{a}$ \\
Angelim vermelho & $1,140 \mathrm{ab}$ & $14,053 \mathrm{a}$ & $14.36 \mathrm{~b}$ & $29.56 \mathrm{~b}$ & $0.05523 \mathrm{~b}$ \\
Breu vermelho & $980 \mathrm{ab}$ & $11,049 \mathrm{~b}$ & $14.45 \mathrm{~b}$ & $32.25 \mathrm{ab}$ & $0.06460 \mathrm{~b}$ \\
Murici & $760 \mathrm{~b}$ & $11,535 \mathrm{~b}$ & $13.38 \mathrm{bc}$ & $29.84 \mathrm{~b}$ & $0.06365 \mathrm{~b}$ \\
Piãozinho & $1,180 \mathrm{a}$ & $14,212 \mathrm{a}$ & $18.08 \mathrm{a}$ & $37.29 \mathrm{a}$ & $0.03223 \mathrm{c}$ \\
Means & 990 & 12,528 & 14.27 & 31.63 & 0.06940 \\
CV & 17.68 & 11.89 & 17.75 & 10.69 & 47.66 \\
\hline
\end{tabular}

* Means followed by the same letter do not differ statistically by the Tukey test at a probability level of 5\%.; MOEd = Dynamic Elasticity Module; MOR = Rupture modulus; ** Surface not sandpapered; CV = Coefficient of variation.

Jesus et al. (2016), studying the behavior of three Amazonian woods (Apulea leiocarpa, Buchenavia capitatae, Clarisia racemosa), reached the results of apparent density from 630 to $860 \mathrm{Kg} / \mathrm{m}^{3}$. Dias and Lahr (2004) characterized 40 Brazilian woods, obtaining average density results of $850 \mathrm{Kg} / \mathrm{m}^{3}$, and for Angelim pedra (Hymenolobium sp.) The density was 1.16 and for Angelim vermelho (Dinizia excelsa) was $1,130 \mathrm{Kg} / \mathrm{m}^{3}$. The apparent density (average) in the study developed was $990 \mathrm{Kg} / \mathrm{m}^{3}$, slightly higher than the study by Dias and Lahr, however, for Dinizia excelsa wood the values were practically identical.

Several studies indicate that surface roughness is strongly influenced by wood density. In general, higher density woods have a lower surface roughness value (Amorim et al., 2013; Lopes, et al., 2014; Teles; Costa; Souza, 2016). However, Zhong, Ng and Hiziroglu (2018) studying the surface roughness of Pinus (Pinus resinosa), Red oak (Quercus rubra) and Nyatoh (Palaquim sp.) Woods, reached the inverse correlations, that is, the lowest roughness in the woods of medium density. The panels of Angelim vermelho and Piãozinho, which are woods of high density, presented low roughness and consequently flat surfaces in this study (Table 4).

High performance of mechanical test panels such as MOE and MOR are associated with bonding quality (Almeida et al., 2017; Amorim et al., 2013; Lima et al., 2008). And according to Kilic, Pürlusoy and Kurnali (2018) and Zhong, Ng and Hiziroglu (2018) surface roughness is intrinsically related in this process. The modulus of elasticity in solid woods are generally larger than in manufactured products, studies using non-destructive techniques found values of 14,976 MPa for Araucaria angustifolia wood (Stangerlin et al.,
2008) and 14,604 MPa for Cordia alliodora (Medeiros Neto; Paes; Segundinho, 2016), values very close to those obtained in this study for Piãozinho wood. Almeida et al. (2017) evaluating the resistance of EGP (Cupressus lusitanica) panels, found maximum values of the modulus of rupture (Tensile/ MOR) of 15.43 $\mathrm{MPa}$, whereas in the studies of Amoah, Kwartng and Dadzie (2014) to evaluate the MOR a Static flexion of EGP panels from African tropical woods (Pterygota macrocarpa, Antiaris toxicaria, Entandrophragma angolense and Entandrophragma cylindricum) obtained average values of $27.04 \mathrm{MPa}$. In this study with EGP panels from Amazon managed woods, the value for Tensile/MOR ranged from 11.06 to $18.08 \mathrm{MPa}$, and Flexion/MOR from 29.21 to $37.29 \mathrm{MPa}$, showing higher rates than woods from other regions.

By evaluating the physical-mechanical characterization data of the wood/EGPs panels with the roughness, the correlation between the roughness and the properties of the products was verified by Pearson's coefficient (Table 5). Pearson's correlation indicates whether or not there is a significant correlation between the studied properties, being directly proportional near $1+$ and inversely proportional near 1-. Lira and Chaves Neto (2006) state that the analysis allows verifying associations or relationships. In all evaluated properties, a significant and directly proportional correlation was detected. For the Flexion/MOR and Roughness tests, although the coefficient was slightly low $\left(\mathrm{R}^{2}=0.42\right)$, it was still considered significant. However, for the Tensile/ MOR and Roughness tests, the correlation was higher and also significant $\left(\mathrm{R}^{2}=0.81\right)$. Showing that the lower the roughness, the greater the tensile strength/MOR of the EGP panel. 
Table 5: Pearson's correlation coefficient, obtained in the correlations between the studied variables.

\begin{tabular}{|c|c|c|c|c|c|}
\hline & Roughness & Apparent density & MOEd & Tensile MOR & Flexion MOR \\
\hline Roughness & & 0.29 & 0.28 & $0.81 *$ & $0.42 *$ \\
\hline Apparent density & & & $0.70 *$ & $0.50 *$ & $0.35 *$ \\
\hline MOEd & & & & $0.40 *$ & 0.20 \\
\hline Tensile MOR & & & & & $0.81 *$ \\
\hline Flexion MOR & & & & & \\
\hline
\end{tabular}

*Significant; test done with 95\% confidence; MOEd= Dynamic elasticity modulus; MOR = Rupture Module.

Using this same correlation method Adorno and Garcia (2003), evaluating the technological characteristics of Eucalyptus grandis and Eucalyptus urophylla wood, find a high correlation between the physical-mechanical properties. In another study, Amorim et al. (2013) evaluated the wettability and roughness of 11 Amazon woods and observed through regression analysis that there was a correlation between roughness and wood density, although the coefficient of determination was relatively low $\left(\mathrm{R}^{2} \approx 0.35\right)$, but highly significant, indicating how the variables vary together.

\section{CONCLUSIONS}

Machining efficiency is the foundation for having flat surfaces with low roughness. The parameters regarding rotational speed, cutting and cutting thickness were essential for the surface quality of the processed parts. The effectiveness of the reduction of sandpapertreated undulations occurred decreasing (grain size) for all panels. EGP Piãozinho presented better surface quality, which consists of lower roughness (lower height of the surface undulations), while EGP Angelim pedra presented irregular surfaces. Surface quality was satisfactory when 120 grain sandpaper was applied to most products. Pearson's correlation showed a highly significant effect of roughness as the variables vary together. It is noteworthy that the wood and EGP Piãozinho in all tests, always presented the best performances.

\section{REFERENCES}

ADORNO, M. F. C.; GARCIA, J. N. Correlações lineares entre as principais características tecnológicas da madeira de clones de Eucalyptus grandis e Eucalyptus urophylla. Scientia Forestalis, (63):44-53, 2003.

ALMEIDA, C. C. F. et al. Avaliação da qualidade da colagem de topo da madeira de Cupressus lusitanica Mill para a produção de painéis colados lateralmente. Scientia Forestalis, 45(113):9-19, 2017.

AMERICAN SOCIETY TESTING AND MATERIALS - ASTM. Standard specification for adhesives used for finger joints in nonstructural lumber products - ASTM D557295. West Conshohocken: ASTM, 2005. 17p.

AMOAH, M.; KWARTENG, F. O.; DADZIE, P. K. Bending properties and joint efficiency of some tropical hardwoods fingerjointed in green and dry states. Journal of the Indian Academy of Wood Science, 11(1):5764, 2014.

AMORIM, M. R. S. et al. Surface wettability and roughness of 11 Amazonian tropical hardwoods. Floresta e Ambiente, 20(1):99-109, 2013.

ASLAN, S.; COS-KUN, H.; KILIC, M. The effect of the cutting direction, number of blades and grain size of the abrasives on surface roughness of taurus cedar (Cedrus libani A. Rich.) woods. Building and Environment, 43(5):696-701, 2008.

ASSOCIAÇÃO BRASILEIRA DE NORMAS TÉCNICAS - ABNT. NBR 7190 - Projeto de Estruturas de Madeira. Rio de Janeiro: ABNT, 1997. 107p.

ASSOCIAÇÃO BRASILEIRA DE NORMAS TÉCNICAS - ABNT. NBR 4287 Especificações geométricas do produto (GPS) Rugosidade: método do perfil-termos, definições e parâmetro da rugosidade. Rio de Janeiro: ABNT, 2002.18p.

AYDIN, I.; ÇOLAKOGLU G. Odun yüzeylernde pürüzlülük ve pürüzlülük ölçüm yöntemler. Artvin Orman Fakültesi Dergisi, 1-2:92-102, 2003.

COSTA TIENNE, D. L. et al. Qualidade de adesão de juntas de madeira de pinus coladas em condições simuladas de serviço interna e externa. Floresta e Ambiente, 18(1):1629, 2011.

CSANÁDY, E.; MAGOSS, E.; TOLVAJ, L. Quality of machined wood surfaces. Basel: Springer International Publishing Switzerland, 2015. 260p. 
DIAS, F. M.; LARH, F. A. R. Estimativa de propriedades de resistência e rigidez da madeira através da densidade aparente. Scientia Forestalis, (65):102-113, 2004.

DIAS JÚNIOR, A. F. et al. Propriedades físicas e acabamento superficial da madeira de eucalipto termicamente tratada. Revista de Ciências Agrárias, 58(3):270-276, 2015.

FERREIRA, G. C.; GOMES, J. I.; HOPKINS, M. J. G. Estudo anatômico das espécies de leguminosae comercializadas no estado do Pará como "angelim". Acta Amazonica, 34(3):387- 398, 2004.

INSTITUTO NACIONAL DE PESQUISAS DA AMAZÔNIA INPA/CPPF. Catálogo de madeiras da Amazônia. Características tecnológicas: área da hidrelétrica de balbina. Manaus: INPA, 1991. 166p.

IWAKIRI, S. et al. Resistência das juntas coladas de madeiras de Inga alba (SW) willd e swartzia recurva poepp. Cerne, 21(3):457-463, 2015.

JESUS, A. G. et al. Comportamento das madeiras de três espécies amazônicas submetidas à secagem ao ar. Nativa, 4(1):31-35, 2016.

KILIC, M.; HIZIROGLU, S.; BURDURLU, E. Effect of machining on surface roughness of wood. Building and Environment, 41(8):1074-1078, 2006.

KILIC, M.; PÜRLUSOY, I.; KURNALI, M. Measuring the surface roughness values of european hop-horn beam (Ostrya Carpinifolia Scop.) wood. Wood Research, 63(2):343-352, 2018.

LI, W. et al. The influences of circular saws with sawteeth of mic-zero-degree radial clearance angles on surface roughness in wood rip sawing. Annals of Forest Science, 74(37):1-9, 2017.

LIMA, C. K. P. et al. Colagem da madeira de clones de Eucalyptus com três adesivos comerciais. Scientia Forestalis, 36(77):73-77, 2008.

LIRA, S. A.; CHAVES NETO, A. Coeficientes de correlação para variáveis ordinais e dicotômicas derivados do coeficiente linear de pearson. Ciências \& Engenharia, 15(1/2): 45-53, 2006.

LOPES, C. S. D. et al. Avaliação da rugosidade superficial da madeira de Eucalyptus sp. submetida ao fresamento periférico. Cerne, 20(3):471-476, 2014.

LUIZÃO, F. J.; VASCONCELOS, H. L. Floresta Tropical Úmida (Manaus). Boletim Técnico da CEPLAC, 71(1):1-13, 1993.
MAGOOS, E. Evaluating of the surface roughness of sanded wood. Wood Research, 60(5): 783-790, 2015.

MAGOOS, E. General regularities of wood surface roughness. Acta Silvatica \& Lignaria Hungarica, 4:81-93, 2008.

MARTINS, S. A. et al. Efeito da usinagem na rugosidade da superfície da madeira de Eucalyptus benthamii Maiden et Cambage. Floresta e Ambiente, 18(2):135-143, 2011.

MEDEIROS NETO, P. N.; PAES, J. B, SEGUNDINHO, P. G. A. Determinações dos módulos de elasticidade e ruptura de madeiras por técnicas não destrutivas e destrutiva. Scientia Forestalis, 44(111):683-690, 2016.

MOURA, L. F.; HERNÁNDEZ, R. E. Evaluation of varnish coating performance for two surfacing methods on sugar maple wood. Wood and Fiber Science, 37(2):355$366,2005$.

NASCIMENTO, C. S. et al. Caracterização tecnológica da madeira de matá-matá (Eschweilera odora Poepp. Miers). In: Seminário Internacional em Ciências do Ambiente e Sustentabilidade na Amazônia. v. 5. Manaus: EDUA, 2018. 14p.

PEREIRA, K. M.; GARCIA, R. A.; NASCIMENTO, A. M. Rugosidade da superfície de madeiras amazônicas. Scientia Forestalis, 46(119):347-356, 2018.

RAABE, J.; DEL MENEZZI, C.; GONÇALEZ, J. Avaliação da superfície de lâminas decorativas de Curupixá (Micropholis venulosa Mart. Eichler). Floresta e Ambiente, 24:e20150054, 2017.

STANGERLIN, D. M. et al. Obtenção do módulo de elasticidade em madeiras de Patagonula americana e Araucaria angustifolia por meio do método ultra-sonoro. Revista Científica Eletrônica de Engenharia Florestal, 11(1):115, 2008.

TELES, R. F.; COSTA, A. F.; SOUZA, M. R. Análise da influência do tratamento preservativo na cor e rugosidade de superfícies de madeiras tropicais. Floresta e Ambiente, 23(1):100108, 2016.

THOMA, H.; PERI, L.; LATO, E. Evaluation of wood surface roughness depending on species characteristics. Maderas. Ciencia y Tecnologia, 17(2):285-292, 2015.

ZHONG, Z. W.; NG, Q. L.; HIZIROGLU, S. Evaluation of bonding strength and surface quality of wood exposed to accelerated soaking. Journal of Tropical Forest Science, 30(4):622-627, 2018. 